Available online at www.jmle.org

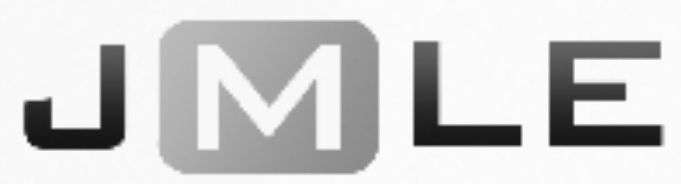

The National Association for Media Literacy Education's

Journal of Media Literacy Education 10 (3), 57 - 79

\title{
Foregrounding Morality: Encouraging Parental Media Literacy Intervention Using the TARES Test for Ethical Persuasion
}

\author{
Kevin J. Pearce \\ Stanley Baran \\ Bryant University
}

\begin{abstract}
In the United States, children are exposed to literally hundreds of thousands of television commercials a year and virtually every aspect of kids' lives are replete with commercial messages. The negative effects of this exposure are well documented. Yet, there remains very little regulation or limit on advertising to children beyond that which exists for adults. Additionally, only about $1 / 3$ of U.S. parents wish for stronger controls. This presents a challenge for media literacy scholars and practitioners. Research has shown that, when presented with information about the negative effects of commercial messages, parents are more likely to adopt some form of media literacy intervention. In this study, we test to see if framing the concept of advertising to children as being unethical (using the TARES test) will increase parents' willingness to engage in medial literacy intervention techniques. Results show that when advertising to children is framed as being unethical, parents indicated a greater willingness to engage in concept-oriented communication as a media literacy intervention than when the negative effects of advertising is presented without an ethical framing.
\end{abstract}

Keywords: media literacy, TARES test, advertising to children, persuasion, interventions

The more than 400 town and city councils England and Wales making up the Local Government Association recently petitioned Britain's Advertising Standards Authority to mandate pop-up health warnings on online product-based games (advergames), arguing that the marketing practice was inherently unethical (Green, 2014). In March, 1972, more than four decades earlier, Boston's Evelyn Sarson, president of the advocacy group Action for Children's Television, challenged her government even more directly. She posed a simple question to 
members of the U. S. Senate's Subcommittee on Communications. That body was taking her testimony as part of its charge to investigate the findings of the recently published Surgeon General's Report on Television and Social Behavior. Focusing her comments specifically on advertising to children, she said to Committee Chair, John Pastore, "I think the analogy is really, would you allow a salesman into your living room to sell something to a 5-year-old?" The Senator from Rhode Island responded, "No, I would not," to which Ms. Sarson countered, "Then why would you allow him to sell to 5-year-olds on television?" (Sarson, 1972, p. 265). Nearly half-a-century later, at least in the United States, there seems still to be no adequate answer to that obvious question.

In the United States, a country in which children are exposed to literally hundreds of thousands of television commercials a year and where virtually every aspect of kids' lives is replete with commercial messages (sponsored community and family events; marketing in their schools and textbooks; products integrated into their television shows, videogames, magazines, social media, websites, and movies; marketing synergies tied to the food they eat, the clothes they wear, the toys they play with; Rideout, 2014), there remains very little, if any, regulation or limit on advertising to children beyond that which exists for adults, specifically, prohibition against "false" or "misleading" advertising (Wilcox et al., 2004). This stands in contrast to most other developed countries. For example, it is illegal to place or integrate products into children's television programming in Great Britain. In Australia, marketers cannot advertise food and beverage products to children under 12 unless those products represent healthy dietary choices, defined as those consistent with established scientific or government standards, nor can marketers use popular characters or celebrities as spokespeople. Ireland has a similar ban. France requires food advertisers to include health messages in their commercials or pay a tax on their ad budgets to fund healthy-eating messages. Italy bans advertising during cartoon programming and in Luxembourg, from all children's programming. Greece forbids the advertising of toys and Germany prohibits ads that make direct offers to kids. Sweden and Norway simply ban all advertising from programming aimed at children under 15 (Sheehan, 2014; Bakir \& Vitell, 2010).

These controls find their basis primarily in the recognition that children, especially young children, are not cognitively capable of understanding advertising's persuasive intent and sophisticated selling techniques. Children's lack of adequate cognition has been demonstrated by a wealth of scholarly research. This work has consistently shown that before age 4, children have no concept of advertising per se, nor can they distinguish between television's advertising and its program content. By age 4 or 5 they are capable making that distinction, but cannot yet comprehend a commercial's persuasive intent. Somewhere between 7 and 11 years old, kids begin to understand commercials' selling intent (Oates, Blades, \& Gunter, 2001; Nairn \& Fine, 2008), but even by 12 their understanding of that persuasive intent was still not on a par with adult levels (Rozendaal, Buijzen, \& Valkenburg, 2011). Similar evidence exists for children's lack of understanding of "non-traditional" advertising such as movie and in-videogame product placements, product licensing, program sponsorship, and advergames. As Laura Owen and her 
colleagues demonstrated, children as old as 10 "appear to have limited knowledge of [these] alternative marketing tactics and consequently lack the cognitive skills to evaluate them critically" (2013, p. 195). The American Psychological Association (APA), in its comprehensive 2004 examination of the issue, drew the parallel between American federal government regulations against "false" and "misleading" advertising to adults and all advertising to children, concluding

it is [legally] unfair and deceptive for commercials to bypass the cognitive defenses against persuasion which adults are presumed to have when they understand that a given message consists of advertising content and can identify the source of the message. If it is unfair and deceptive to seek to bypass the defenses that adults are presumed to have when they are aware that advertising is addressed to them [that is, false advertising], then it must likewise be considered unfair and deceptive to advertise to children in whom these defenses do not yet exist. (Wilcox, 2004, p. 21)

The recognition of this imbalance of power between cognitively underdeveloped young children and a massive, multi-billion dollar marketing industry staffed with MBAs and Ph.Ds led to a movement within the APA to ban its members from assisting those who would target children with their advertising (Clay, 2000).

Parents, too, are not particularly enamored with advertising to children. As research by Caroline Oates and her colleagues discovered, "Parental concerns about advertising to children are not new and have been reported in many countries. Concerns tend to cluster around a number of issues, mainly the amount of advertising to which children are exposed, its nature or features, and advertising used to promote specific products which parents view as inappropriate. Parents have also expressed concerns about their children's ability to understand advertisement and what might be the effects, for example, on behaviour [sic]" (Oates, Newman, \& Tziortzi, 2014, pp. 115-116). Nana Lee Moore came to a similar conclusion when she compared parental attitudes toward television advertising aimed at children in four countries, the United States, the United Kingdom, New Zealand, and Sweden. She demonstrated that "parents in the United States have the same attitudes as do parents in the United Kingdom, Sweden, and New Zealand. It can also be conclude that parents in these four countries strongly agree that: (a) advertising makes children put pressure on them to buy things; (b) the more advertising children watch, the more they want the product advertised; (c) children are exposed to too much television advertising; and, (d) advertising persuades people to buy products they do not really need" $(2011$, p. 111).

There were important national differences, however, on what to do about that dissatisfaction with advertising to kids. Despite the fact that the United Kingdom and Sweden already have quite stringent regulation of children's television advertising, $87 \%$ of UK parents and $72 \%$ of those in Sweden wanted even stronger government regulation. In the U. S., only $35.5 \%$ of parents wished for stronger controls. In fact, the identical percentage of American parents, $35.5 \%$, 
wanted weaker oversight of advertising to their kids (the proportions wanting weaker limits in the UK and Sweden were 1\% and 5\% respectively). The fact that only a third of American parents wanted more stringent government regulation of children's television advertising is especially surprising given the fact that, when compared to parents in the other nations studied, U. S. parents felt more strongly than their international peers that most advertisements deceive children, children are deceived by advertising more easily than are adults, and children are exposed to too much TV advertising.

Why the disconnect? Why are parents who seemingly hold negative attitudes toward children's advertising unwilling to demand or take action based on those attitudes? Why do a majority of American youth engage media free from parental rules or restrictions (Rideout, Foehr, \& Roberts, 2010) and are free to "manage their time themselves" when engaging with electronic media (ReportLinker, 2017)? In fact, a good deal of scholarly evidence demonstrates that parents "typically do not exert much control over children's media use" (PadillaWalker et al., 2012, p. 1154). Distrust of government regulation; lack of trust in science; a cultural characteristic of individuality and self-reliance; and seemingly reasonable industry counterarguments may well explain the problem.

\section{Distrust of Government Regulation}

There may be some reason to mistrust government regulation of children's media (The Television Act of 1990, designed to increase the availability of educational and informational programming aimed at kids actually had the reverse and perverse effect of doing just the opposite; Wilson, Kunkel, \& Drogos, 2008). Nonetheless, half of the American population believes there is too much government regulation (Newport, 2014). In fact, Americans have little faith in government at all to solve important social and economic problems. Fewer than 1 in 5 people trusts the government always or most of the time (Pew, 2015a). The parental self-defense therefor becomes, "Sure, marketing to kids may be distasteful, but I don't need some government regulator to tell me how to raise my children! The government isn't going to say what my kids can watch or eat!"

\section{Lack of Trust in Science}

Sociologist Gordon Gauchat examined public trust in science, examining 26 years of data from the General Social Survey (GSS), the bi-annual survey that contains a standard set of demographic, behavioral, and attitudinal questions. In all, Dr. Gauchat was able to track data from more than 30,800 respondents, and what he discovered was a definite overall decline in trust in science in the United States in the years between 1974 and 2010 (2012). And while most Americans, 8 in 10, agree that science has made their lives better, when it comes to specific scientific findings, there are wide gaps, as much as $40 \%$, between what science has demonstrated and what people believe (Pew, 2015b). Both distrust in government and distrust in scientific findings are exacerbated, if not reinforced, by historic lows in trust of the news media that report on these important aspects of social life; only 1 in 3 Americans has a "fair amount" or "great deal" of trust in the news media 
(Swift, 2016). A parent might therefore ask, "Can I really trust the science connecting kids' media consumption with rising rates of obesity, diabetes, heart disease, and even death (Bickham et. al., 2013; Grøntved \& Hu, 2011) or those news reports linking kids advertising to my kids' preference for unhealthy food (Boyland \& Halford, 2013)?”

\section{Individualistic Cultural Characteristics}

American culture is highly individualistic (Hofstede, 1983). In general, people in individualistic cultures tend to value the goals, needs, and rights of the individual over fealty to the larger community. Parents might then reason, "O. K., maybe there's a little too much kids advertising for my liking, but I'll handle it my way. Anyway, I'm doing a better job than those other parents!" In fact, research has demonstrated the operation of a parental third-person effect by which parents believe media negatively affect other people's children, especially in the areas of materialism (other kids become more materialistic, not mine), and positively affect their own (my kids learn more good things than do the kids of others; Meirick et al., 2009).

\section{Seemingly Reasonable Industry Arguments}

The marketing and adverting industries offer several arguments that have face validity that offer safe cognitive haven for those disinclined to be moved to action regarding adverting to children. The first industry argument is that advertising is actually good for kids. Marketing researcher Chris Preston (2005) claims that not only is marketing to kids economically important- "The socialisation [sic] of children into consumers is necessary given the capitalist system's need for future expenditure" (p. 61) — but that it is essential to child development: "Children use advertising to learn of the tools of social interaction that will facilitate self-expression and social conformity, both for themselves and their family, and also to find out about the social significance of brands. . .Advertising explains to children what things mean, things that you can buy and things you can do" (p. 62). And after presenting the critics' arguments against the practice, he concludes:

It is all too easy for advertising to be accused of irresponsible influence upon children, yet if the issue is investigated it emerges as an inconsistent position. It is difficult to take seriously that advertising is irresponsible for promoting materialism amongst children. Our society is intrinsically materialist, and advertising is therefore consistent with its context. Within the context of a materialistic society advertising provides a useful function for children by providing information about brands and their symbolic and social meaning. Within that context therefore it can be viewed as socially responsible. (p. 66)

To accept this argument, parents would have to be comfortable with the ideas of consumer products as expressions of the self (you are what you buy), social 
conformity as a good thing, and an intrinsically materialistic society as inevitable. But any cognitive discomfort with this perspective on humanity and the world can be mitigated by the second and third industry arguments: marketers who target children have imposed on themselves self-regulation and self-regulation must suffice because advertisers have First Amendment rights to promote their products (O'Brien, 2011). To accept these arguments, parents would have to trust profitdriven entities to police themselves (in the case of advertising to children, these self-regulatory programs have been a demonstrated failure; e.g., Kunkel, McKinley, $\&$ Wright, 2009) and ignore the fact that even First Amendment rights can be limited (You can't yell "Fire!" in a crowded theater), especially in the case of the protection of children (e.g., Ginsberg v. New York, 1968). Accepting these arguments as reasonable, it isn't irrational for parents to wonder, "I don't know, maybe marketing to my kids isn't that bad after all."

\section{Living with Children in the Real World}

Parents face real-world pressures to let their kids settle in front of a screen so they can manage their hectic lives, and they must also deal with their kids' demands that they be allowed to do so. Padma Ravichandran and her colleagues (2016) at the National Center for Health Research assert that parents are now actually encouraging the use of electronic devices while they are trying to accomplish other things. As a result, for many parents, if not most, there already exists good reason to overlook their distaste for marketing to children and work, however consciously or unconsciously, to mitigate their ambivalence over the issue. Add distrust of government regulation and science, a cultural proclivity toward individuality and self-reliance, and the presence of apparently reasonable counterarguments, and it becomes clear that parents, even the most wellintentioned, can find themselves simply taking the path of least resistance in a highly commercialized, heavily mass-mediated world. What may be necessary, then, is to change the terms of the debate. This may be possible through a media literacy intervention.

\section{MEDIA LITERACY INTERVENTIONS}

A wealth of research has demonstrated that media literacy interventions, efforts to build specific media literacy skills, can produce positive effects on media knowledge, media criticism, and the perceived realism of media content, and that interventions can mitigate or enhance media influence on beliefs, attitudes, selfefficacy, and actual behavior (Jeong, Cho, \& Hwang, 2012). After conducting a meta-analysis of scores of intervention efforts, Se-Hoon Jeong and his colleagues argued that media literacy interventions are "an effective approach for reducing potentially harmful effects of media messages. Intervention effects were found across divergent topics for diverse audiences, for a broad range of media-related (e.g., knowledge) and behavior-related (e.g., attitudes and behaviors) outcomes. The results that intervention effects did not vary according to target age, the setting, audience involvement, and the topic suggest that interventions can be equally 
effective across a spectrum of settings (e.g., school, community, or lab), age groups, levels of audience involvement, and topics (e.g., alcohol, violence, and sex)" (p. 464).

Of particular relevance to advertising and children is the work of Moniek Buijzen and Patti Valkenburg, who showed that a particular intervention, parental mediation, could help elementary school children better deal with television advertising (2005). They found that parents were able to reduce their children's level of materialism and the frequency with which they demanded the products they saw advertised by engaging in active commercial mediation; that is, while watching television with their children, parents deliberately offered commentary and judgments about the commercials and actively explained the ads' techniques and selling intent. Parents who engaged in concept-oriented communication with their kids - actively discussing consumer matters with their children, even away from the viewing situation, helping them become more critical consumers-were able not only to reduce their kids' levels of materialism and demand for advertised products, but they could also reduce the amount of parent-child conflict resulting from kids' demands for what they see on TV. Both techniques were more effective in improving children's responses to advertising than was restricting their viewing.

This suggests, and research demonstrates (Padilla-Walker et al., 2012), that the issue of parents' attitudes toward children's advertising is key, because parents' willingness to engage in any form of mediation between their children and the advertising they see is clearly a function of how important that intervention is to them. In other words, and in terms of this study, can parents' well-demonstrated negative attitudes toward marketing to their children sufficiently withstand the arguments that might otherwise dissuade them from taking action? And while there is a long history of evidence that attitudes toward behaviors are predicative of behavioral intention (Rasmussen et al., 2016), there is also evidence specifically of the relationship between parental attitudes toward marketing to children and their willingness to act. For example, Doster and Tyrrell (2011) showed that parents' acceptance of in-school marketing efforts was tied to personal evaluative criteria, specifically their judgment of the involved company's ethical reputation, their perception of the company's motivation for being in the school, and the specifics of the marketing approach being untaken. Bakir and Vitell (2009) found a positive relationship between the intensity of parents' attitudes toward the ethics of various forms of food advertising to children and their behavioral intentions, that is, the likelihood that they would engage in some sort of mediation with their children. More recently, Eric Rasmussen and his colleagues demonstrated that "parents' critical thinking about media is positively associated with both active and restrictive mediation, relationships mediated by parents' attitudes toward parent-child interactions about media." This led them to argue "that media literacy programs aimed at improving parents' critical thinking about media may be an effective way to alter children's responses to media exposure and that these media literacy programs should promote positive attitudes toward parental mediation" (2016, p. 1). 


\section{Foregrounding the Ethics of Advertising to Children}

The Doster and Tyrrell (2011) and Bakir and Vitell (2009) research does more than demonstrate the relationship between parental attitudes toward marketing to children and behavior (willingness to allow in-school marketing to their children) and behavioral intention (willingness to take action). Both identified the ethics of advertising to children as an important factor in parents' motivations to act. For the purpose of this study, ethics is the process of finding rational justifications for actions when the values people hold come into conflict. Ethics, according to media ethicist Patrick Plaisance, "begins when elements of a moral system conflict." Ethics, he writes, "focuses on the rightness of a given action: How can we say this particular action would be the right thing to do?" (2014, p. 9; italics in original). Specifically addressing the ethics of advertising to children, Margaret Haefner explained the values in play (and therefore in conflict). Americans' embrace of advertising, she wrote, reflects "the values that dominate the cultures of many American corporations-profit and efficiency. These values emanate from the egoistic roots of capitalism which claim that the pursuit of selfish individual interests is the only moral imperative." She points to Kirkpatrick's "moral justification of advertising," quoting his argument that advertising "represents the implementation of an ethics of egoism - the communication of one rational being to another rational being for the egoistic benefit of both" (1986, p. 512). "Yet," she counters, "with respect to children and advertisers, the equal rationality of communicators cannot be presumed" (1991, p. 87). Therefore, she concludes advertising to children is fundamentally immoral.

We've seen that when it comes to advertising to children, social science has more than adequately destroyed the equal-rationality-of-communicators argument serving as the "moral justification for advertising." So what Haefner and many others (e.g., Tripathi \& Singh, 2014; Mabaquiao, 2012; Nairn \& Fine, 2008; Wilcox et al., 2004; Paine, 1993) argue is that advertising to children is not an economic issue, it is an ethical issue. These moral critiques of the practice rely primarily on two ethical theories, John Rawls's veil of ignorance (1971) and Emmanuel Kant's moral principle of respect for the autonomy of persons (1987).

Briefly, Rawls argues that when faced with choosing a route of action, especially when competing alternatives find their basis in competing values, people should remove themselves from the actual situation in which they find themselves and place themselves in an "original position," where all social differences between people are eliminated and no one knows what his or her position in this new order of things will be once the veil is lifted. As a result, the actions people choose to take "in this context of imagined equality. . .will seek to protect the most vulnerable, because they do not know whether they themselves will emerge from behind the veil as the most vulnerable party. If such moral reasoning were applied to decisions about advertising that affects children," explains ethicist Haefner, "decision makers would no doubt seek to protect the liberties of vulnerable children. Behind the veil, they would see that, as children, they would be at a psychological disadvantage in the economic marketplace" (1991, p. 88). 
Ethical arguments against advertising to children based on Kant's thinking rely on the premise of human dignity and autonomy. Kant draws a distinction between I/Thou and I/It relationships. In I-Thou relationships, each person is fully human; that is, he or she is fully autonomous in making free and rational decisions; in I-It relationships, others are objects; they are means to various ends. When others are objects, they are robbed of their human dignity. Ethicist Napoleon Mabaquiao (2012) explains that

persons are free and rational while non-persons are not. As such, treating persons in the manner appropriate to them, which regards or respects their freedom and rationality, is tantamount to treating persons as ends; while treating persons in the manner not appropriate them, which does not regard or respect their freedom and rationality, is tantamount to treating persons as non-persons or merely as means. A concrete way of determining whether one violates the autonomy of other persons is to consider whether the action one performs towards these other persons is something to which these other persons would give their voluntary and informed consent. If it is an action to which they would not give their voluntary consent it means that such action is forced on them or that they are coerced to accept such action and hence it does not respect their freedom; while if it is an action to which they would not give their informed consent it means that there is some deception involved and hence their rationality is not being respected. (italics in original; p. 114)

As for advertising to children, he concluded, "If children are not yet capable of autonomous decisions, how do children figure in the ethical evaluation of business [consumer] ads that mainly focus on human autonomy? We earlier noted that ads violate human autonomy not just by preventing the exercise of the capacity for making autonomous decisions, but also by preventing the development of such capacity. It is the latter that applies to children. And so while children are not yet autonomous, ads nonetheless violate the personhood of children for they prevent the development of the children's capacity for autonomy. Also, we noted that ads violate human autonomy through their implicit content or the promotion of consumerism. On closer inspection, it is actually the children who are especially vulnerable to the promotion of the consumerist lifestyle, for it is actually at the level of children where the internalization of this lifestyle begins, which they will carry with them as they become adults" (p. 118).

Business ethicist Lynn Paine (1993) combined the moral reasoning of Rawls and Kant to find ethical fault in children's advertising along three dimensions. The first is the principle of truth (children are cognitively incapable of differentiating reality and fantasy). "To the extent that children develop false beliefs and unrealistic expectations as a result of viewing commercials, moral reservations about children's advertising are justified. To the extent advertisers know that children develop false beliefs and unreasonable expectations, advertisers' devotion to truth and to responsible consumption is suspect" (p. 662). Second is the principle 
of respect for the personhood of children. Children are not capable of giving voluntary or informed consent not only to the consumption of advertising but to the use of the products presented in that advertising; as such, marketing to children treats them as non-persons, as mere means to satisfy their own profit motives and those of the companies behind the advertising. Finally, there is the principle of avoiding pain or harm. Paine identifies child/parent conflict over the purchase of the advertised products; children's depression at being denied those products and the animosity it creates toward parents when they are unable or unwilling to buy those products; children's frustration when they discover that the advertised features of the products are not real; children's sadness at witnessing lifestyles portrayed in commercials that their own families cannot afford; and parental pain at their inability to satisfy their children's desires for advertised products and the lifestyles they purportedly enrich.

\section{The TARES Test as Parental Media Literacy Intervention}

Advertising to children is unethical. But can that reality move parents to action? There is evidence that it can and does. Ethical judgments form a central construct in several moral decision-making models (e.g., Dubinsky \& Loken, 1989; Jones, 1991), and research has demonstrated that people are more likely to state their behavioral intentions in situations where they believe the relevant actions to be ethical (Bass et al., 1999). Moreover, ethical judgements ultimately affect people's behaviors through the expression of those behavioral intentions (Hunt \& Vitell, 1986).

This study tests the efficacy of a media literacy intervention, aimed at parents, to foreground the ethical failures of advertising to children and, as such, influence their attitudes toward that practice and, ultimately, their behavioral intentions. It takes as its foundation Sherry Baker and David Martinson's TARES Test for ethical persuasion (2001). These ethicists worried that "there is a very real danger that advertisers and public relations practitioners will play an increasingly dysfunctional role in the communications process if means continue to be confused with ends in professional persuasive communications. Means and ends will continue to be confused unless advertisers and public relations practitioners reach some level of agreement as to the moral end toward which their efforts should be directed." Their test, "defines this moral end, establishes ethical boundaries that should guide persuasive practices, and serves as a set of action-guiding principles directed toward a moral consequence in professional persuasion" (p.148). The TARES Test, although not designed specifically for advertising to children, has obvious application, especially given its basis in the moral thinking of Rawls and Kant. Its five principles are Truthfulness (of the message), Authenticity (of the advertiser), Respect (for the child), Equity (of the persuasive appeal), and Social Responsibility (what does it contribute to the common good).

As such, two hypotheses were tested. The first tests the effect of intervention in general and the second tests the effect of an ethics-based media literacy intervention: 
Hypothesis 1: Parents who participate in a media literacy intervention critical of advertising to children will indicate more of a willingness to perform media literacy interventions with their children than will parents who do not participate in any media literacy intervention.

Hypothesis 2: Parents who participate in a media literacy intervention premised on the ethical failings of children's advertising will indicate more of a willingness to perform media literacy interventions with their children than will parents who participate in an intervention that, while critical of advertising to children, ignores its ethical failings.

\section{METHOD}

\section{Participants and Procedure}

This study utilized a primarily volunteer sample. Subjects were recruited through advertisements and in requests in online forums. Additionally, students at a small, private, northeastern university were asked to have their parents participate if they had a younger sibling under the age of 18 . One hundred forty two parents of children under the age of 18 were recruited to answer a questionnaire in order to assess our hypotheses. Participants included 49 males (34.5\%) and 93 females $(65.5 \%)$. Average age was 37.8 years old.

Once they agreed to participate, subjects were randomly assigned to one of three experimental conditions (ethics-specific intervention, no-ethics intervention, and no intervention). Based on assigned condition, participants watched either one of two media literacy interventions or they did not watch any intervention. Subjects were then asked to complete a questionnaire that contained demographic information as well as the Media Literacy Intervention Scale.

\section{Measures}

Intervention Conditions: Two interventions were created and uploaded to YouTube in the form of Prezi slide presentations, complete with compelling images on all slides and quiet background piano music (available at https://www.youtube.com/watch?v=P0iobhtBl-8). The beginning of both the ethics and no-ethics video interventions were the same. Both included information about the harmful effects of television viewing on children. However, the ethics video condition also included information explaining how, using the TARES Test of ethical persuasion, marketing to children does not meet the basic standards of ethical persuasion. The no-ethics version was 2:38 minutes long. The ethics version ran 2:13 minutes longer to include the additional information specific to the TARES Test and the ethical implications of adverting to children. A transcript of verbal content for the two versions is shown in Appendix A below.

Media Literacy Interventions: In order to assess willingness to participate in media literacy interventions, a scale was created to measure the intervention categories of restriction, active mediation, and concept-oriented communication (from Buijzen \& Valkenburg, 2005). The 15-items scale contained 5 questions 
measuring each dimension. Questions were based on the literature and contained items such as "Parents should simply forbid a child from watching television commercials" and "When shopping with their child, parents should point out the discrepancies between what the TV commercials said about a product and its reality" (see Appendix B). Cronbach's Alpha for the concept-oriented communication dimension as .90 $(\mathrm{M}=17.11$, $\mathrm{SD}=6.74)$. Alpha for the restriction condition was $.93(\mathrm{M}=24.50, \mathrm{SD}=5.96)$, and for the active mediation dimension it was $.89(\mathrm{M}=24.75, \mathrm{SD}=5.87)$. The items are shown in Appendix B.

\section{RESULTS}

A one-way between-groups analysis of variance was conducted to examine the differences among the three experimental conditions on the scores on the Media Intervention Scale and for the dimensions of concept-oriented communication, restriction, and active mediation. Tukey's post-hoc analysis was used to examine specific differences among conditions. Hypothesis 1 predicted that parents who participate in a media literacy intervention critical of advertising to children (the noethics condition) will indicate more of a willingness to perform media literacy interventions with their children than will parents who do not participate in any media literacy intervention (the no-training condition). There was a statistically significant difference between the no-ethics media literacy training condition and the no-training condition on all dependent measures. As Table 1 shows, the noethics media literacy training condition scored higher on the Media Intervention Scale $(M=67.71)$ than the no-training condition $(M=57.33) F(2,139)=15.831$, $p$ $<.05$. The no-ethics media literacy training condition also scored higher than the no-training condition on the dimensions of restriction $(\mathrm{M}=25.85, \mathrm{M}=21.48$, respectively), $\mathrm{F}(2,139)=7.90, \mathrm{p}<.05)$, active mediation $(\mathrm{M}=25.69, \mathrm{M}=21.80$, respectively) $\mathrm{F}(2,139)=7.73, \mathrm{p}<.05$, and concept-oriented communication $(\mathrm{M}=$ $16.17, \mathrm{M}=14.05$, respectively) $\mathrm{F}(2,139)=11.85, \mathrm{p}<.05$. Therefore, hypothesis one is supported.

Hypothesis 2 predicted that parents who participate in a media literacy intervention premised on the ethical failings of children's advertising (ethics condition) will indicate greater willingness to perform media literacy interventions with their children than will parents who participate in an intervention that, while critical of advertising to children, ignores its ethical failings (no-ethics condition). Results showed there were there were no significant differences between the overall Media Intervention Scale as well as the dimensions of restriction and active mediation. However, there was a significant difference between the two groups on the concept-oriented communication. As Table 1 shows, those in the ethics media literacy training condition indicated they were more likely to use concept-oriented communication interventions $(M=20.20)$ than those in the no-ethics media literacy training condition $(\mathrm{M}=16.17) \mathrm{F}(2,139)=11.85, \mathrm{p}<.05$. Therefore, hypothesis 2 is partially supported. 
Table 1

ANOVA Comparisons of Training Condition and Media

\begin{tabular}{lcccccccc} 
& \multicolumn{2}{c}{ All Media Interventions } & \multicolumn{2}{c}{ Restrictive } & \multicolumn{2}{c}{ Active Mediation } & \multicolumn{2}{c}{ Concept-Oriented } \\
\cline { 2 - 8 } & \multicolumn{1}{c}{ Mean } & SD & Mean & SD & Mean & SD & Mean & SD \\
\cline { 2 - 8 } No Video & $57.33^{\mathrm{ab}}$ & 9.42 & $21.48^{\mathrm{cd}}$ & 5.68 & $21.80^{\mathrm{ef}}$ & 5.6 & $14.05^{\mathrm{g}}$ & 5.63 \\
& & & & & & & & \\
No Ethics & $67.71^{\mathrm{a}}$ & 11.79 & $25.85^{\mathrm{c}}$ & 4.71 & $25.69^{\mathrm{e}}$ & 5.59 & $16.17^{\mathrm{g}}$ & 4.9 \\
& & & & & & & & \\
Ethics & $71.83^{\mathrm{b}}$ & 14.94 & $25.54^{\mathrm{d}}$ & 6.45 & $26.09^{\mathrm{f}}$ & 5.64 & $20.20^{\mathrm{g}}$ & 7.65 \\
\hline
\end{tabular}

Similar superscripts denotes significant differences

\section{DISCUSSION}

We recognize that marketing to children is not in the best interests of either parent or child. Yet, unlike parents in other countries, American parents seem unwilling to favor government regulation of kids advertising, nor are they typically willing to control or limit their children's access to commercial media and therefore the marketing they contain. There may simply be too many "reasonable" countervailing arguments, regardless of their merit, allowing parents to comfortably manage any cognitive dissonance that might arise from the disconnect between their attitudes toward marketing to children and their behaviors in that realm (Festinger, 1957).

But what if parents' negative attitudes toward advertising to children could be reinforced or even bolstered by a moral dimension? Yes, they accept that marketing to children is bad for their kids and bad for their relationship with their kids. They also sense that it is unfair. But what would happen if they were to judge it immoral or unethical?

The confirmation of hypothesis one demonstrates that parents who are reminded of the negative aspects and unfairness of marketing to children are willing to commit to intervening with their own children in a variety of ways, from restricting kids' access to commercial media to active mediation, to conceptoriented communication. Whether this media literacy intervention reminded them of, persuaded them toward, or succeeded in moving them to think critically about marketing to their children may well be beside the point. Whichever might be the case, and most likely different respondents read the intervention differently, the more salient point is that what we see in the partial confirmation of hypothesis two is the value, even power, of asking parents to think critically about advertising to children.

Parents who experienced the ethics-oriented media literacy intervention, like those who underwent the non-ethics intervention, expressed the behavioral intent to intervene in their children's consumption of advertising. But unlike those other parents, they expressed the intention to engage in the most involved, most demanding, yet most effective form of intervention, concept-oriented 
communication, that is, carrying the media literacy lesson with them in a variety of contexts, even away from the media consumption setting.

Few parents need to be persuaded about the negative effects of marketing to children. Perhaps the goal of media literacy interventions aimed at parents should be designed, not to simply remind them of what they already know, but to change the terms of the debate. Even the most harried parents, those willing to "look the other way" when their kids' time in front of a screen buys them time to manage their adult lives, recognize the difference between "not good" and "immoral."

The information gained from this study can be used in a variety of ways. Parents who understand and accept ethics-based arguments against advertising to children were more likely engage in concept-oriented communication with their children. Many national organizations (i.e. Center for Media Literacy, Connect Safely, and Media Literacy Now) have developed some kind of media literacy training/information designed for parents. This information can be reworded to highlight the unethical nature of advertising to children. Additionally, some school districts engage with parents to help educate their children on the importance of media literacy. These school districts should include an ethical component when engaging with parents.

Future research might focus on parents' susceptibility to moral or ethical appeals. For example, Bakir and Vitell (2009) found a relationship between parents' level of moral intensity, the "extent of issue-related moral imperative in a situation" (p. 301) and their behavioral intention to involve themselves in matters of marketing to children. An interesting question, then, might be the relative effectiveness of ethics-oriented interventions on parents holding varying levels of moral intensity along its different dimensions (Jones, 1991). For example, moral intensity varies by the magnitude of consequences (the cumulative harm associated with an act, in this case, advertising to children); probability of effect (the likelihood that advertising to children does indeed cause harm); temporal immediacy (how quickly do those effects occur); concentration of effect (how many others see the act of advertising to children as causing harm); proximity (how close socially and culturally are those affected); and social consensus (how "good" or "bad" is the act generally seen). While the literature makes it clear that parents do not like, nor do they trust marketing to children, they may hold those opinions for varying reasons and at varying degrees of depth and their willingness to intervene with their children may well be related to those differences.

Another possible route of inquiry might be what motivates parents to move from "behavioral intention" to "behavior." It is one thing to recognize the need for action and committing one's self to that action and actually performing that action. As this research argues, it is this last step that parents, especially in the United States, find most difficult. Nonetheless, this study does demonstrate that appeals to the parents' moral and ethical judgments about advertising to children can be effective media literacy tools. 


\section{REFERENCES}

Baker, S., \& Martinson, D. L. (2001). The TARES test: Five principles for ethical persuasion. Journal of Mass Media Ethics, 16, 148-175.

Bakir, A, \& Vitell, S. J. (2010). The ethics of food advertising targeted toward children: Parental viewpoint. Journal of Business Ethics, 91, 299-311.

Bass, K., Barnett, T., \& Brown, G. (1999). Individual difference variables, ethical judgments, and ethical behavioral intentions. Business Ethics Quarterly, 9, 183-205.

Bickham, D. S., Blood, E. A., Walls, C. E., Shrier, L. A., \& Rich, M. (2013). Characteristics of screen media use associated with higher BMI in young adolescents. Pediatrics, 131, 1-7.

Boyland, E. J., \& Halford, J. G. C. (2013). Television advertising and branding. Effects on eating behaviour and food preferences in children. Appetite, 62, 236-241.

Buijzen, M., \& Valkenburg, P. M. (2005). Parental mediation of undesired advertising effects. Journal of Broadcasting \& Electronic Media, 49, 153-165.

Clay, R. A. (2000). Advertising to children: Is it ethical? Monitor on Psychology, 31, 52.

Doster, L., \& Tyrrell, J. M. (2011). Marketing communications in the classroom: The parents' view. Journal of Marketing Communications, 17, 1-15.

Dubinsky, A. J., \& Loken, B. (1989). Analyzing ethical decision making in marketing. Journal of Business Research, 19, 83-107.

Festinger, L. (1957). A theory of cognitive dissonance. Stanford, CA: Stanford University Press.

Gauchat, G. (2012). Politicization of science in the public sphere: A study ofpublic trust in the United States, 1974 to 2010. American Sociological Review, 77, 167-187.

Ginsberg v. New York, 390 U.S. 629 (1968).

Green, C. (2014, March 29). Food giants target children with addictive 'advergames'. Independent. Retrieved from https://www.independent.co.uk/news/uk/home-news/food-giants-targetchildren-with-addictive-advergames-9222302.html

Grøntved, A., \& Hu, F. B. (2011). Television viewing and risk of type 2 diabetes, cardiovascular disease, and all-cause mortality: A meta-analysis. Journal of the American Medical Association, 305, 2448-2455.

Haefner, M. J. (1991). Ethical problems of advertising to children. Journal of Media Ethics, 6, 83-92.

Hofstede, G. (1983). National cultures in four dimensions: A research-based theory of cultural differences among nations. International Studies of Management \& Organization, 13, 46-74. 
Hunt, S. D., \& Vitell, S. (1986). A general theory of marketing ethics. Journal of Macromarketing, 6, 5-16.

Jeong, S. H., Cho, C. H., \& Hwang, Y. (2012). Media literacy interventions: A meta-analytic review. Journal of Communication, 62, 454-472.

Jones, T. M. (1991). Ethical decision-making by individuals in organizations: An issue-contingent model. Journal of Management Review, 16, 366-395.

Kant, I. (1987). Fundamental Principles of the Metaphysics of Morals. T. K. Abbott, trans. New York: Prometheus Books.

Kirkpatrick, J. 1986. A philosophical defense of advertising. Journal of Advertising, $15,42-48,64$.

Kunkel, D., McKinley, C., \& Wright, P. (2009). The impact of industry selfregulation on the nutritional quality of foods advertised on television to children. Children Now. Retrieved from: http://ourcommunityourkids.org/media/2906/adstudy_2009.pdf

Livingstone, S., \& Helsper, E. J. (2006). Does advertising literacy mediate the effects of advertising on children? A critical examination of two linked research literatures in relation to obesity and food choice. Journal of Communication, 56, 560-584.

Mabaquiao, N. M. (2012). The ethics of business ads directed at children. Philosophia, 41, 112-120.

Meirick, P. C., Sims, J. D., Gilchrist, E. S., \& Croucher, S. M. (2009). All the children are above average: Parents' perceptions of education and materialism as media effects on their own and other children. Mass Communication and Society, 12, 217-237.

Moore, N. L. (2006). Parental Attitudes toward children's television advertising: Comparative analysis of the United States, United Kingdom, Sweden, and New Zealand. Dissertation, Capella University. UMI Number: 3274709.

Nairn, A., \& Fine, C. (2008). Who's messing with my mind? The implications of dual-process models for the ethics of advertising to children. International Journal of Advertising, 27, 447-470.

Nairn, A., \& Dew, A. (2007). Pop-ups, pop-unders, banners and buttons: The ethics of online advertising to primary school children. Journal of Direct, Data and Digital Marketing Practice, 9, 30-46.

Newport, F. (2014, September 15). Few Americans want more gov't regulation of business. Gallup. Retrieved from: http://www.gallup.com/poll/176015/fewamericans-gov-regulation-business.aspx

Oates, C., Newman, N., \& Tziortzi, A. (2014). Parents' beliefs about, and attitudes towards, marketing to children. In Blades, M., Oates, C., Blumberg, F., and Gunter, B., eds., Advertising to children: New directions, new media (pp. 115-136). New York: Palgrave Macmillan.

Oates, C., Blades, M., \& Gunter, B. (2001). Children and television advertising: When do they understand persuasive intent? Journal of Consumer Behaviour, 1, 238-245. 
O’Brien, G. (2011). Marketing to children: Accepting responsibility. Business Ethics, May 31. Retrieved from: http://businessethics.com/2011/05/31/1441-marketing-to-children-accepting-responsibility/

Owen, L., Lewis, C., Auty, S., \& Buijzen, M. (2013). Is children's understanding of nontraditional advertising comparable to their understanding of television advertising? Journal of Public Policy \& Marketing, 32, 195-206.

Padilla-Walker, L. M., Coyne, S. M., Fraser, A. M., Dyer, W. J., \& Yorgason, J. B. (2012). Parents and adolescents growing up in the digital age: Latent growth curve analysis of proactive media monitoring. Journal of Adolescence, 35, 1153-1165.

Paine, L. S. (1993) Children as consumers: An ethical evaluation of children's television advertising. In T. I. White (ed.), Business ethics: A philosophical reader. New York: Macmillan.

Pew Research Center. (2015a, November 23). Beyond distrust: How Americans view their government. Retrieved from: http://www.peoplepress.org/2015/11/23/beyond-distrust-how-americans-view-theirgovernment/

Pew Research Center. (2015b, January 28). Opinion differences betweenpublic and scientists.Retrieved from: http://www.pewinternet.org/2015/01/29/publicand-scientists-views-on-science-and-society/pi_2015-01-29_science-andsociety-00-01/

Plaisance, P. L. (2014). Media ethics (2 ${ }^{\text {nd }}$ ed). Los Angeles: Sage. Preston, C. (2005). Advertising to children and social responsibility. Young Consumers: Insight and Ideas for Responsible Marketers, 6, 61-67.

Rasmussen, E. C., White, S. R., King, A. J., Holiday, S., \& Densley, R. L. (2016). Predicting parental mediation behaviors: The direct and indirect influence of parents' critical thinking about media and attitudes about parent-child interactions. Journal of Media Literacy Education, 8, 1-21.

Ravichandran, P., de Bravo, B. F., \& Beauport, R. (2016). Young children and screen time (television, DVDs, computer). National Center for Health Research. Retrieved from: http://center4research.org/child-teen-health/earlychildhood-development/young-children-and-screen-time-television-dvdscomputer/

Rawls, J. (1971). A Theory of justice. Cambridge, MA: Harvard University Press.

Rideout, V. (2014). Advertising to children and teens: Current practices. San Francisco: Common Sense Media.

Rideout, V. J., Foehr, U. G., \& Roberts, D. F. (2010). Generation M2: Media in the lives of 8-to 18-year-olds (Publication \#8010). Menlo Park, CA: Kaiser Family Foundation. Retrieved August 24, 2017 from http://files.eric.ed.gov/fulltext/ED527859.pdf

ReportLinker. (2017). When you give a kid a tablet, he'll ask for more time. Reportlinker.com. Retrieved April 27, 2017 from https://www.reportlinker.com/insight/give-kid-tablet-ask-time.html 
Rozendaal, R., Buijzen, M., \& Valkenburg, P. (2011). Children's understanding of advertisers' persuasive tactics. International Journal of Advertising, 30, 329-350.

Sarson, E. (1972). Hearings before the Subcommittee on Communications of the Committee on Commerce, United States Senate, Ninety-Second Congress, Second Session on the Surgeon General's Report by the Scientific Advisory Committee on Television and Social Behavior. Washington, DC, March 2, 22,28 , and 24.

Sheehan, K. B. (2014). Contemporary controversies in advertising. Los Angeles: Sage.

Swift, A. (2016, September 14). Americans' trust in mass media sinks to new low. Gallup. Retrieved from http://news.gallup.com/poll/195542/americans-trustmass-media-sinks-new-low.aspx

Tripathi, R. \& Singh, V. P. (2014). Corporate social responsibilty (CSR) and ethical issues in marketing. International Journal of Management and International Business Studies, 4, 297-308.

Wilcox, B. L., Kunkel, D., Cantor, J., Dowrick, P., Linn, S., \& Palmer, E. (2004). Report of the APA Task Force on Advertising and Children. Washington, DC: American Psychological Association.

Wilson, B. J., Kunkel, D., \& Drogos, K. L. (2008). Educationally/insufficient? An analysis of the educational quality \& availability of children's E/I programming. Children Now. Retrieved from https://pbskids.org/lions/parentsteachers/pdf/childrennow_report.pdf

\section{Appendix A}

\section{Transcript of Video Manipulation}

Both the ethics and non-ethics versions are similar with the exception of the inclusion of the TARES test in the ethics version.

\begin{tabular}{|l|l|}
\hline ETHICS VERSION & NON-ETHICS VERTION \\
\hline $\begin{array}{l}\text { A Simple Question: Would you allow a } \\
\text { salesperson into your living room to sell } \\
\text { something to your 5-year old? }\end{array}$ & $\begin{array}{l}\text { A Simple Question: Would you allow a } \\
\text { salesperson into your living room to sell } \\
\text { something to your 5-year old? }\end{array}$ \\
$\begin{array}{l}\text { Another Simple Question: Then why would you } \\
\text { allow the world's most powerful salespeople to } \\
\text { sell to your 5-year old using the most } \\
\text { sophisticated and effectively persuasive } \\
\text { technologies? }\end{array}$ & $\begin{array}{l}\text { Another Simple Question: Then why would you } \\
\text { allow the world's most powerful salespeople to } \\
\text { sell to your 5-year old using the most } \\
\text { sophisticated and effectively persuasive } \\
\text { technologies? }\end{array}$ \\
$\begin{array}{l}\text { Children are exposed to thousands of television } \\
\text { commercials a year. Every aspect of their lives is } \\
\text { replete with commercial messages! }\end{array}$ & $\begin{array}{l}\text { Children are exposed to thousands of television } \\
\text { commercials a year. Every aspect of their lives is } \\
\text { replete with commercial messages! }\end{array}$ \\
Half of all advertising aimed at kids is for & Half of all advertising aimed at kids is for \\
\hline
\end{tabular}


snacks, fast food, and other unhealthy eating options.

The effects of all this exposure are imprinted on their brains. Restructuring of the brains holds over to adulthood.

What's the big deal? My kid knows what's going on!

Maybe not...

- Children are NOT cognitively capable of understanding advertising's sophisticated selling techniques.

- $\quad$ Before age 4 , children cannot distinguish between a TV advertisement and a TV program.

- $\quad$ By age 4 or 5 they can make the distinction, but cannot comprehend a commercial's persuasive intent.

- It isn't until children are much older that they begin to understand the persuasive intent of television commercials.

What's the big deal? So what if they see a bunch of ads?

Well, those ads have an effect....

- Dissatisfaction with parent's finances.

- Nagging their parents and the resulting conflict.

- $\quad$ Obesity and generally diminished health and well-being.

- Development of a materialistic world view.

- $\quad$ Sense of personal inadequacy.

- Increased cynicism.

Is there a law?

- There are regulations that advertisements cannot be false or misleading.

- $\quad$ But there are NO regulations on advertising specifically to children.

- If kids can't tell and advertisement is an ad, isn't that advertisement, by definition, "false"?

- If kids don't understand the selling intent of an ad, isn't that ad "misleading"? snacks, fast food, and other unhealthy eating options.

The effects of all this exposure are imprinted on their brains. Restructuring of the brains holds over to adulthood.

What's the big deal? My kid knows what's going on!

Maybe not...

- Children are NOT cognitively capable of understanding advertising's sophisticated selling techniques.

- Before age 4, children cannot distinguish between a TV advertisement and a TV program.

- $\quad$ By age 4 or 5 they can make the distinction, but cannot comprehend a commercial's persuasive intent.

- It isn't until children are much older that they begin to understand the persuasive intent of television commercials.

What's the big deal? So what if they see a bunch of ads?

Well, those ads have an effect....

- Dissatisfaction with parent's finances.

- Nagging their parents and the resulting conflict.

- $\quad$ Obesity and generally diminished health and well-being.

- Development of a materialistic world view.

- $\quad$ Sense of personal inadequacy.

- Increased cynicism.

Is there a law?

- $\quad$ There are regulations that advertisements cannot be false or misleading.

- But there are NO regulations on advertising specifically to children.

- If kids can't tell and advertisement is an ad, isn't that advertisement, by definition, "false"?

- If kids don't understand the selling intent of an ad, isn't that ad "misleading"? 
What do other countries do?

France requires food advertisers to include health messages in commercials of pay a tax.

In Australia, marketers can only advertise healthy food and beverage products to children under 12.

Italy bans advertising during cartoon programming.

Sweden and Norway ban all advertising from programming aimed at children under 15 .

What is the difference between the U.S. and these countries?

These countries view advertising to children ad UNETHICAL. You decide using the TARES test for ethical communication.

T: Trustworthiness of the Message

A: Authenticity of the Persuader

R: Respected for the Persuaded

E: Equality of the Appeal

S: Social Responsibility for the Common Good

Trustworthiness of the message.

- $\quad$ The message must not only be true but truthful.

- It is possible to deceive without lying.

- Truthfulness is the advertisers' intention not to deceive and the intention to provide children with truthful information they need to make good decisions.

Cap'n Crunch is "part of a healthy breakfast". In this ad, so are the curtains and table!

Authenticity of the Persuader.

- Authenticity is integrity and personal virtue in action.

- Authenticity means sincerity in promotion products and services to people.

- Authenticity involves loyalty and commitment to principle.

Is he sincere when he says that a new toy will make your child the most popular kid on the
What do other countries do?

France requires food advertisers to include health messages in commercials of pay a tax.

In Australia, marketers can only advertise healthy food and beverage products to children under 12.

Italy bans advertising during cartoon programming.

Sweden and Norway ban all advertising from programming aimed at children under 15 .

What is the difference between the U.S. and these countries?

These countries view advertising to children very differently! They recognize the importance of the issue. Public perception of the importance of media regulation is different in many parts of the world. 
K. Pearce and S. Baran | Journal of Media Literacy Education 2018 10(3), 57 - 79

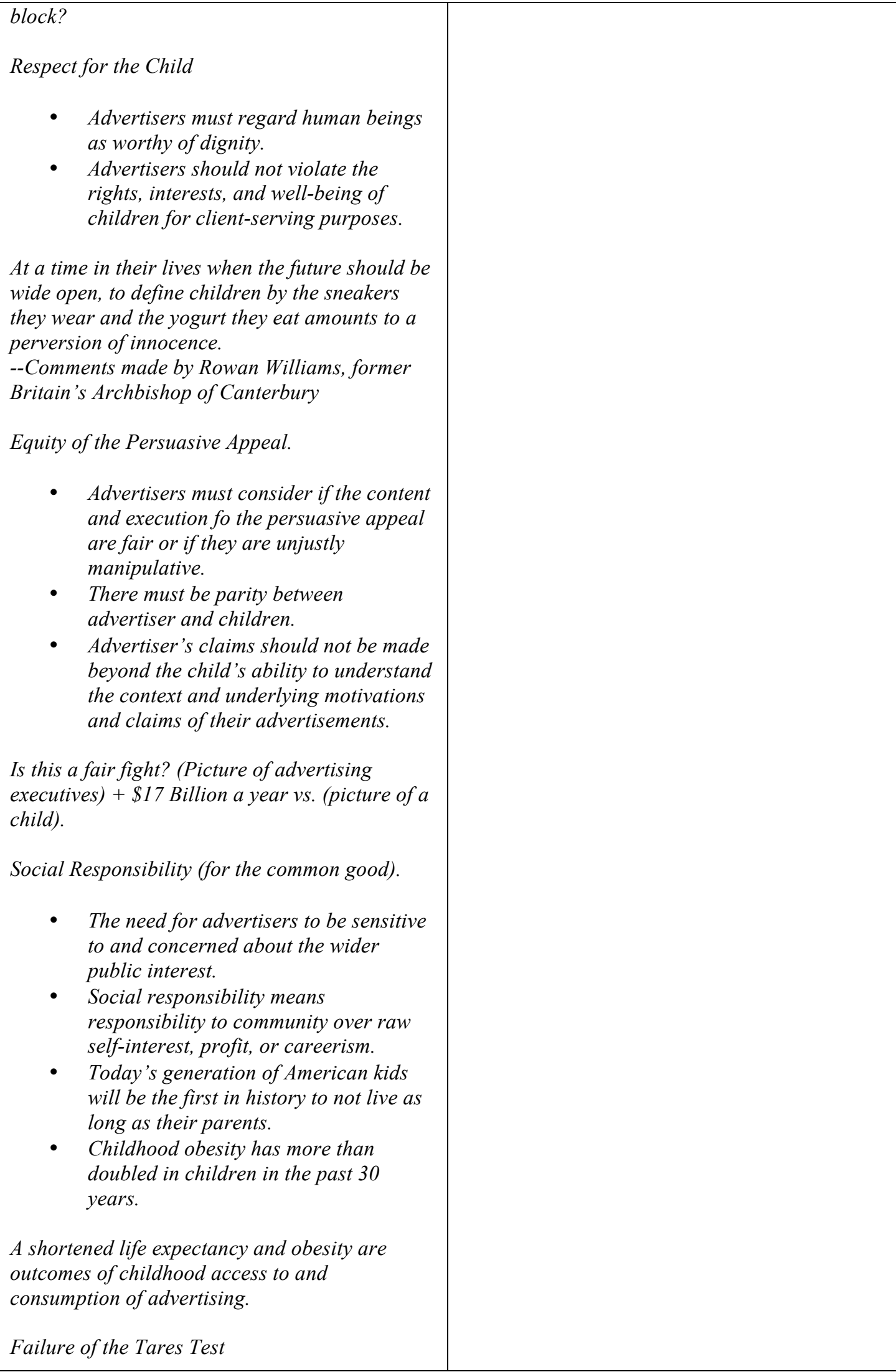


1) Truthfulness: FAIL!

2) Authenticity: FAIL!

3) Respect: FAIL!

4) Equity: FAIL!

5) Social Responsibility: FAIL!

So what can you, a parent, do?

- Restriction

- Active Mediation

- Concept-Oriented Communication

Restriction: Limiting kids' access to commercial media.

Active Mediation: Discussing the persuasive nature of advertising WHILE watching television with them.

Concept-Oriented Communication: Discussing with them in the persuasive nature of advertising AWAY from the screen.

Thank you. Please continue on with the survey.
So what can you, a parent, do?

- Restriction

- Active Mediation

- Concept-Oriented Communication

Restriction: Limiting kids' access to commercial media.

Active Mediation: Discussing the persuasive nature of advertising WHILE watching television with them.

Concept-Oriented Communication: Discussing with them in the persuasive nature of advertising AWAY from the screen.

Thank you. Please continue on with the survey.

\section{Appendix B \\ Measures of Media Literacy Interventions}

\section{Concept Oriented Mediation}

1. When shopping with their child, parents should point out the discrepancies between what the TV commercials said about a product and its reality.

2. When a child asks for a product by brand name, parents should discuss the contribution of advertising to that preference and why it might not be the best product in that category.

3. When the opportunity arises, parents should relate to their child that her/his worth as a person is not dependent on the things she/he possesses.

4. If a child asks for a product that he/she sees on a television advertisement, parents should talk to him/her about how what they saw on television might not be true.

5. If a child asks for a pair of popular shoes he/she sees in a television advertisement, parents should tell him/her that, while they might be popular, they might not be the best shoes and that the advertisement is intended to convince him/her otherwise.

\section{Active Mediation}

1. When watching TV with a child, parents should make sure that the child knows that they don't need all the products they see advertised.

2. When watching TV with a child, parents should point out the different production techniques that make a product seem better on the screen than it actually is.

3. When watching TV with a child, parents should mention the fact that despite what a commercial might imply, having that specific product or brand won't make the child a happier or a better person. 
K. Pearce and S. Baran | Journal of Media Literacy Education 2018 10(3), 57 - 79

4. When watching TV with a child, parents should make sure the child understands some of the tricks advertisers use to make a product seem more necessary than it really is.

5. When watching TV with a child, parents should periodically discuss the nature of advertisements so he/she knows that the intent is to sell a product.

\section{Restriction}

1. Parents should simply forbid a child to watch commercial TV.

2. Parents should limit their child's consumption of commercial TV to only those times they can be present.

3. Parents should limit my child's consumption of commercial TV to only a few, very specific programs that they trust.

4. Parents should only allow their children to view programs with ads edited out.

5. If possible, parents should change the channel away from commercials to make sure that their child sees as few commercials as possible. 